\title{
AN ESTUARINE MODEL FOR PENNSYLVANIAN LAGERSTÄTTEN
}

FELDMAN, Howard R., MAPLES, Christopher G., Kansas Geological Survey, 1930 Constant Ave., Lawrence KS 66047; ARCHER, Allen W., WEST, Ronald R., Department of Geology, Kansas State University, Manhattan KS; KVALE, Erik P., Indiana Geological Survey, 611 N. Walnut Grove, Bloomington IN 47405.

Estuaries were important sites of deposition throughout most of the Pennsylvanian in the Midcontinent. Modern estuaries typically occur within flooded river valleys where marine and fresh waters mix. Characteristic estuarine circulation results in locally high rates of deposition of muddy sediment that can lead to good preservation of fossils. Several Pennsylvanian conservat-Lagerstätten are best interpreted as having formed within ancient estuaries. Three types of estuarine deposits have been identified. Type 1 estuarine systems are large-scale transgressive systems that start with fluvial sands overlying an erosional surface. This is overlain successively by middle-estuarine laminated mudstone, and finally marine mudstone and shale. Well-preserved fossils occur in laminated mudstones and siltstones. This sequence may include within in it type 3 estuarine Lagerstätten. An example is the Douglas Group (Missourian, Kansas).

Type 2 estuarine Lagerstätten consist of thin estuarine deposits confined to narrow paleochannels. This includes the Garnett (Missourian, Kansas) and Hamilton (Virgilian, Kansas) deposits, both of which contain articulated vertebrates and well-preserved plants. Both channels are filled with mixed siliciclastic and carbonate sediments. Fine grained facies from which the best fossils are recovered in both contain evidence of tidal deposition, although tidal rhythmicity is best developed in the Hamilton channel. Plant assemblages in both are dominated by the conifer Walchia, probably indicating a relatively dry climate.

Type 3 estuarine Lagerstätten consist of thick gray-shale wedges that overlie coals. The best-known example is the Francis Creek Shale (Desmoinesian, Illinois). A relatively wet climate is indicated by abundant fern and seed-fern foliage. Laminations in shale facies commonly show well-developed tidal rhythmicity. A typical stratigraphic succession starts with laminated shale overlying coal. This grades upwards into flaser and lenticular bedding to ripple and then large-scale cross-bedded sandstone. Upright trees rooted in the coal indicate rapid burial. Well-preserved fossils are recovered from early-diagenetic siderite concretions from the laminated shale.

Preservation of fossils is best in laminated mudstones deposited in middle-estuarine environments where conditions are ideal for good preservation. In all cases so far studied the zones of best preservation are well laminated and have sparse (if any) burrows and sessile benthic fossils. Most of the well-preserved organisms are terrestrial, nektonic, or at least mobile. Brackish and fluctuating salinities restricted scavenging and burrowing organisms that may scatter skeletons. High turbidity and deposition rate may have further discouraged many organisms. Matching bedding rhythmicity with tidal cycles allows calculation of depositional rates of $1 \mathrm{~cm}$ or more of compacted sediment per 2-week neap-spring tidal cycle. This is consistent with the high rates of deposition known from modern tidal environments. High depositional rates assured that any organism that fell to the sea floor was buried in a few hours to a few days. Once buried anoxic conditions established around decaying carcasses may have led to early mineralization. 